\title{
PENGARUH LAMA PERENDAMAN EKSTRAK KULIT BATANG "KAJU BA'T" (Aglaia tomentosa) TERHADAP EFEKTIVITAS INSEKTISIDA NABATI PADA HAMA GUDANG KACANG HIJAU Callosobruschus sp (COLEOPTERA : BRUCHIDAE).
}

\author{
Mardiah Sarah, Sri Wahyuni, Willybrordus lanamana \\ Program Studi Agroteknologi, Fakultas Pertanian, Universitas Flores \\ Diah_marsyah@yahoo.co.id
}

\begin{abstract}
Effect of soaked bark of "Kaju Ba'i" (Aglaia tomentosa) as an insecticide and its effectiveness on the Green Bean Warehouse Pest Callosobruschus sp (Coleoptera: BRUCHIDAE).

This study aims to determine the influence of soaking bark extract "Kaju Ba'i" (Aglaia tomentosa) and its effectiveness as a botanical insecticide of the green beans warehouse pest Callosobruschus spp.

The experiment was conducted at the Laboratory in the Faculty of Agriculture University of Flores, Ende, from September to October 2010. The research used a completely randomized design with 5 treatments of K0 (control), K1 (bark extract Kaju Ba'i immersed for one day), K2 (bark extract Kaju Ba'i immersed for two days), K3 (Extract Kaju bark Ba'i immersed for three days), K4 (bark extract Kaju Ba'i immersed for four days) each treatment was repeated 10 times. Observed variables included mortality, contact nerve toxins and anti-oviposition activity.

The results showed that the treatment $\mathrm{K} 4$ possesses the highest level of effectiveness, and cause mortality as contact poison (99\%), nerve toxins (2.7\%) and anti-oviposition $(75 \%)$.
\end{abstract}

Key words: Duration of immersion, Kaju Ba'i, Callosobruschus sp,

\section{PENDAHULUAN}

Kacang hijau merupakan tanaman pangan di daerah tropis yang telah lama ditanam di Indonesia dan berpotensi untuk terus dikembangkan. Tingkat produksi tanaman kacang hijau dalam beberapa tahun terakhir umumnya kurang stabil, pada tahun 2004 total produksi sebanyak 314.565 ton (Pusat data dan Informasi Pertanian, 2004) sedangkan produksi pada tahun 2008 sebesar 208.059 ton (BPS, 2008). Penurunan tingkat produksi kacang hijau salah satunya disebabkan oleh serangan hama dan penyakit. Kerusakan yang ditimbulkan tidak terbatas pada tanaman yang masih ada di lapang, tetapi juga dapat merusak biji yang ada di penyimpanan. Salah satu hama pasca panen yang sering menimbulkan kerusakan pada kacang hijau adalah Callosobruchus sp. Pengendalian umumnya dilakukan dengan penggunaan bahan kimia. Namun cara tersebut menyebabkan pangan yang tersimpan terkontaminasi dengan residu bahan kimia berbahaya. Oleh sebab itu perlu pengadaan insektisida alternatif yang lebih aman. Salah satu cara dengan memanfaatkan ekstrak tumbuhan yang aman dan ramah lingkungan (Hermawati, 2004).

Insektisida nabati adalah bahan aktif tunggal atau majemuk yang berasal dari tumbuhan dan dapat digunakan untuk mengendalikan 
organisme pengganggu tumbuhan (OPT). Insektisida nabati berfungsi sebagai penolak, penarik, antifertilitas (pemandul), racun kontak, racun perut dan aktivitas lainnya.

Indonesia sebagai daerah tropis memiliki flora yang beragam dan terdapat banyak jenis tumbuhan yang dapat dimanfaatkan untuk pengendalian hama. Penelitian tentang famili tumbuhan yang berpotensi sebagai insektisida nabati dari penjuru dunia telah banyak dilaporkan dan lebih dari 1500 jenis tumbuhan dapat berpengaruh buruk terhadap serangga. Laporan dari berbagai propinsi di Indonesia menyebutkan lebih dari 40 jenis tumbuhan berpotensi sebagai pestisida nabati (Direktorat BPTP \& Ditjenbun, 1994). Di Indonesia terdapat 50 famili tumbuhan penghasil racun. Famili tumbuhan yang dianggap merupakan sumber potensial insektisida nabati adalah Meliaceae, Annonaceae, Asteraceae, Piperaceae dan Rutaceae (Arnason et. al., 1993), namun tidak menutup kemungkinan untuk ditemukannya famili tumbuhan lain yang berpotensi sebagai insektisida nabati.

Nimba (Azadirachta indica A. Juss) merupakan tanaman dari famili Meliaceae dan tersebar di daratan India. Di Indonesia tanaman tersebut banyak ditemukan di sekitar Provinsi Jawa Tengah dan Jawa Timur. Ekstrak biji tanaman mimba mengandung senyawa aktif utama Azadiraktin yang memiliki aktivitas insektisida, antifeedant dan penghambat perkembangan serangga (Kardinan, 2001) serta berpengaruh terhadap reproduksi berbagai serangga. Insektisida komersial dengan formulasi dasar ekstrak nimba (neem) telah dipasarkan di Amerika Serikat dan India. Selain bersifat sebagai insektisida, jenis-jenis tumbuhan tertentu juga memiliki sifat sebagai fungisida, virusida, nematisida, bakterisida, maupun rodentisida.

Tanaman Kaju Ba'i (Aglaia tomentosa) merupakan salah satu tanaman dari famili Meliaceae yang diduga berpotensi sebagai pestisida nabati. Penelitian sebelumnya menyebutkan bahwa tanaman dari genus aglaia mempunyai senyawa aktif yang bersifat insektisida. Novizan (2002) berhasil mengidentifikasi senyawa aktif yang bersifat insektisida dari ranting Aglaia odorata atau yang lebih dikenal pacar cina sebagai rokaglamida. Senyawa aktif utama yang bersifat insektisida ini termasuk dalam golongan benzofuran. Pada daun A. odorata selain rokaglamida juga ditemukan dan tiga senyawa turunannya, yaitu desmetilrokaglamida, metil rokaglat dan rokaglaol.

Di Kabupaten Ende tanaman "Kaju Ba'i" (Aglaia tomentosa) dapat ditemukan di daerah Detusoko dan Tenda. Dari hasil wawancara tanaman ini pernah digunakan sebagai insektisida nabati oleh petani di kawasan Kelimutu. Sampai saat ini belum ada informasi tentang efektivitas tanaman "Kaju Ba' $i$ " khususnya mengenai lama perendaman. Oleh karena itu penelitian tentang "Pengaruh lama perendaman ekstrak kulit batang "Kaju Ba'i" (Aglaia tomentosa) terhadap efektivitas insektisida nabati pada hama gudang kacang hijau Callosobrunchus sp (Coleoptera : Bruchidae)" dianggap penting dan perlu dilakukan.

\section{BAHAN DAN METODE}

Penelitian ini dilaksanakan selama 6 bulan, di Laboratorium Pertanian Universitas Flores. Bahan yang dibutuhkan adalah kacang hijau, Callosobruchus sp, aquades, metanol, ekstrak kasar Kaju Ba'i. Alat yang dibutuhkan adalah gelas ukur, cawan Petri, pipet, toples pembiakan, 
mikroskop, pipet, pisau, blender, kain kasa, timbangan, aspirator, rotary evaporator, kertas HVS, penggaris, pensil, bolpoint, spidol, labu erlemeyer, saringan ukuran 100 mesh, kertas saring wathman, kertas label dan kamera.

Penelitian ini menggunakan Rancangan Acak Lengkap dengan empat perlakuan ditambah satu kontrol sehingga menjadi 5 perlakuan, setiap perlakuan masing-masing diulang 10 kali sehingga terdapat 50 unit percobaan.

Adapun perlakuan yang diuji adalah:

K0 = Kontrol (aquades), K1 = Ekstrak kulit batang Kaju Ba'i yang direndam selama satu hari. K2 = Ekstrak kulit batang Kaju Ba'i yang direndam selama dua hari. K3 = Ekstrak kulit batang Kaju $B a$ ' $i$ yang direndam selama tiga hari. K4 = Ekstrak kulit batang Kaju $B a ' i$ yang direndam selama empat hari

Pelaksanaan penelitian meliputi langkah - langkah sebagai berikut :

\section{Ekstraksi kulit batang Каји Bai’i (Aglaia tomentosa)}

Kulit batang Kaju Ba'i yang diambil dibersihkan lalu dicacah dan dikering anginkan selama 2-3 hari, lalu diblender. Hasil blenderan diayak menggunakan saringan ukuran 100 mesh, kemudian direndam dalam menggunakan metanol dengan rasio 1:7 (100 gram dalam $700 \mathrm{ml}$ methanol) untuk mendapatkan $1000 \mathrm{ml}$ rendaman dan direndam selama 1,2,3 dan 4 hari. Hasil rendaman disaring dengan menggunakan kertas saring wathman, bahan aktif dari metanol dilakukan dengan menggunakan rotary evaporator. Ekstrak Kaju Ba'i kemudian diencerkan meggunakan aquades dengan rasio 1:1, dan siap untuk diaplikasikan.

\section{Pembiakan Callosobruchus sp}

Pembiakan dilakukan dengan cara memasukkan imago Callosobruschus sp (tetua) yang diambil dari kacang hijau terinfeksi ke dalam toples berisi kacang hijau yang belum terinfeksi Callosobruschus sp selama 3 hari untuk mendapatkan turunan pertama $(\mathrm{F} 1)$. Setelah F1 didapat, imago Callosobruschus sp (F1) dimasukkan kembali ke dalam toples berisi kacang hijau yang belum terinfeksi selama 3 hari untuk mendapatkan turunan kedua (F2). Kegiatan ini dilakukan berulang ulang hingga persediaan serangga terpenuhi.

\section{Aplikasi racun kontak}

Aplikasi racun kontak dilakukan dengan cara menyemprotkan larutan ekstrak kasar secara merata keseluruh permukaan cawan Petri, kemudian diinfestasi dengan 20 ekor imago Callosobruchus sp. Jumlah mortalitas diamati setiap 3 jam selama 2 hari.

\section{Aplikasi racun syaraf, dan antioviposisi}

Kacang hijau direndam dalam larutan ekstrak kasar selama 15 menit lalu diletakkan dalam toples kemudian dimasukkan 20 ekor imago Callosobruchus sp kedalam toples, pengamatan dilakukan setiap 3 jam selama 3 hari.

Adapun yang menjadi variabel pengamatan adalah :

1. Mortalitas racun kontak (\%)

Racun kontak adalah racun yang mengakibatkan kematian pada serangga apabila bersinggungan langsung dengan insektisida tersebut.

Variabel pengamatan mortalitas serangga pada aktivitas racun kontak yang ditentukan dalam presentase menggunakan rumus:

$$
\mathrm{MS}=\frac{\mathrm{Msp}}{\mathrm{Pla}} \mathrm{x} 100 \%
$$


Keterangan :

MS : Mortalitas

Msp : Mortalitas setelah perlakuan

Pla : Populasi awal

2. Mortalitas racun syaraf (\%)

Racun syaraf adalah insektisida masuk melalui trachea serangga dalam bentuk partikel mikro. Serangga akan mati bila menghirup partikel mikro insektisida dalam jumlah yang cukup.

Mortalitas serangga pada aktivitas racun syaraf ditentukan dengan rumus

$$
P M=\frac{M s p}{P l a} \times 100 \%
$$

Keterangan :

PM : Peningkatan mortalitas

Msp : Mortalitas setelah perlakuan

Pla : Populasi awal

3. Penurunan aktivitas peletakkan telur atau antioviposisi (\%).

Aktivitas anti ovoposisi merupakan aktivitas tidak meletakkan telur yang diketahui dari ada dan banyaknya jumlah telur pada kacang hijau perlakuan. Menurut Prijono (1988), dapat lihat dari penurunan jumlah telur serangga karena pengaruh perlakuan, yang dinyatakan dalam persentase dan ditentukan dengan rumus :

$$
P T \frac{J p t}{J t k} \times 100 \%
$$

Keterangan :

PT : Penurunan aktivitas bertelur

Jtp : Jumlah telur pada kacang hijau perlakuan

Jtk : Jumlah telur pada kacang hijau kontrol

\section{Analisis Data}

Data diolah dengan menggunakan prosedur rancangan acak lengkap (RAL) dan dianalisis menggunakan uji $\mathrm{F}$ taraf 5\%, jika antar perlakuan menunjukkan hasil yang berbeda nyata maka analisis akan dilanjutkan dengan uji Duncan's. untuk melihat keeratan hubungan antara lama perendaman dan tingkat efektivitas dilakukan uji regresi (Gomez,1987).

\section{HASIL DAN PEMBAHASAN}

\section{Mortalitas Racun Kontak}

Hasil analisis sidik ragam menunjukkan bahwa waktu perendaman ekstrak kulit batang "Kaju Ba'i" terhadap mortalitas serangga Callosobruschus sp pada racun kontak berpengaruh sangat nyata. Hal ini dapat dilihat pada pengamatan 3 jam pertama sampai 3 jam ke - 16 (Tabel 1)

Tabel 1 Mortalitas Callosobruschus sp pada tiap perlakuan perendaman akibat aktivitas racun kontak

\begin{tabular}{ccc}
\hline Perlakuan & $\mathrm{n}$ & Mortalitas (\%) \\
\hline K0 & 10 & $4 \mathrm{de}$ \\
K1 & 10 & $25 \mathrm{~d}$ \\
K2 & 10 & $42 \mathrm{c}$ \\
K3 & 10 & $68 \mathrm{~b}$ \\
K4 & 10 & $99 \mathrm{a}$ \\
\hline
\end{tabular}

Keterangan: angka-angka yang diikuti huruf yang sama pada kolom yang sama, berarti tidak berbeda nyata pada uji duncan's taraf 5\%. Data ditransformasi dengan $\square X+0,5$

Hasil analisis statistik dari tabel 1 menunjukkan bahwa perlakuan $\mathrm{K} 4$ dengan perendaman 4 hari menyebabkan

mortalitas Callosobruschus tertinggi sebanyak 99\%. Hal tersebut diakibatkan adanya 
pengaruh lama perendaman yang dapat meningkatkan jumlah bahan aktif "Kaju $B a$ ' $i$ " sehingga menyebabkan kecepatan senyawa yang berkerja pada Callosobruschus sp berbeda. Perlakuan K4 memiliki jumlah senyawa yang lebih banyak dibandingkan perlakuan lain sehingga lebih efektif meningkatkan mortalitas serangga. Semakin tinggi jumlah bahan aktif suatu senyawa, maka racun yang mengenai kulit serangga akan bekerja lebih efektif, sehingga dapat menghambat pertumbuhan dan menyebabkan kematian serangga lebih banyak (Sutoyo, 1997). Ditinjau dari toksisitas, suatu senyawa dikatakan efektif bila mampu mematikan 80\% hewan uji (Murfon dan Norton 1984 dalam Budiarto, 2000), oleh sebab itu perlakuan K4 dianggap efektif karena mampu meningkatkan mortalitas di atas $80 \%$.

Mortalitas Callosobruschus sp perlakuan K3 (68\%) K2 (42\%) dan K1 $(25 \%)$ masing-masing berbeda sangat nyata tetapi tidak mengakibatkan mortalitas diatas $80 \%$ sehingga ketiga perlakuan tersebut dianggap belum efektif sebagai pestisida nabati. Penurunan tingkat mortalitas serangga disebabkan oleh jumlah bahan aktif yang mengenai tubuh serangga lebih sedikit sehingga daya kerja bahan aktif lebih lambat. Jumlah bahan aktif yang terkandung dalam ekstrak pada setiap perlakuan dipengaruhi oleh lama perendaman. Semakin lama tingkat perendaman, maka semakin meningkatkan keefektifitasan bahan aktif sehingga mortalitas Callosobruschus sp akan meningkat.

Mortalitas serangga paling rendah pada perlakuan K0 sebanyak $4 \%$ dan mortalitas Callosobruschus sp terjadi pada hari kedua. Uji pra penelitian sebelumnya menunjukkan bahwa serangga Callosobruschus sp yang diberi perlakuan tanpa makan dan dimasukkan ke dalam cawan Petri mengalami mortalitas pada hari kedua, keadaan yang demikian menandakan bahwa mortalitas yang terjadi tidak disebabkan oleh perlakuan tetapi akibat menurunnya daya kesintasan.

Hubungan antara lama perendaman dan peningkatan mortalitas serangga Callosobruschus sp akibat aktivitas racun kontak juga diperlihatkan dengan persamaan regresi $\mathrm{Y}=1,0948+0,5434$ $\mathrm{X}$ berikut:

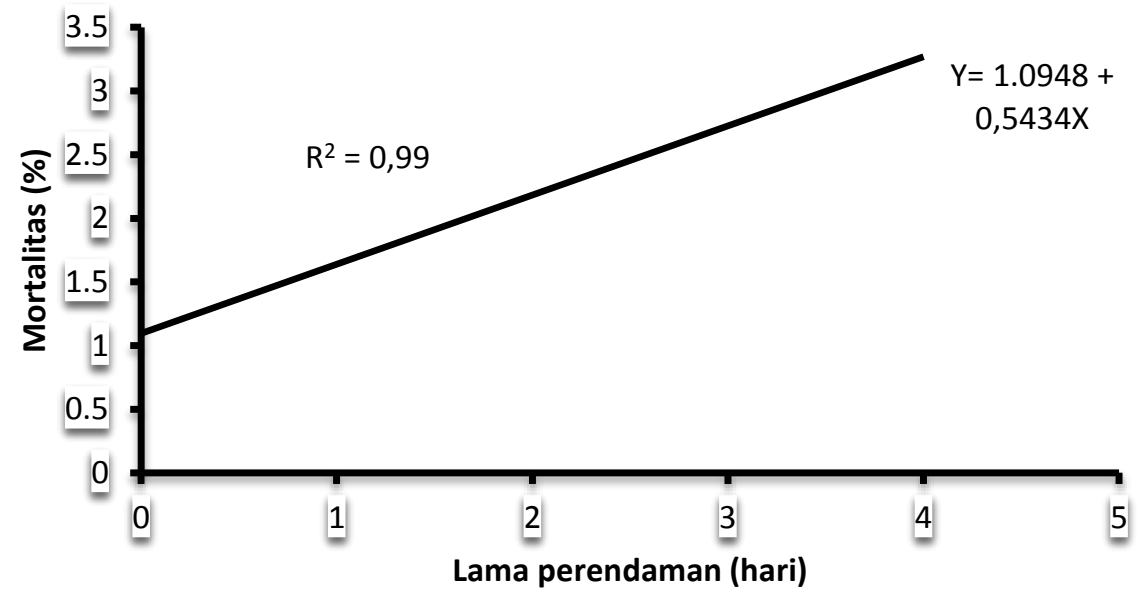

Gambar 1 Persamaan regresi antara lama perendaman Kaju Ba’i dan mortalitas serangga Callosobrushus sp pada aktivitas racun kontak 
Dari grafik di atas dapat dilihat hubungan antara lama perendaman dan mortalitas serangga, dimana semakin lama perendaman maka semakin tinggi mortalitas serangga Callosobruschus sp. Lama perendaman meningkatkan mortalitas serangga sebanyak $0,5434 \%$ pada setiap taraf perendaman, sedangkan mortalitas serangga tanpa perlakuan perendaman sebanyak $1,0948 \%$. Peningkatan mortalitas serangga Callosobruschus sp pada racun kontak 99\% dipengaruhi oleh lama perendaman.

Mortalitas Callosobruschus sp disebabkan oleh jenis kandungan bahan aktif "Kaju Ba' $i$ " yang mengandung senyawa alkaloid, dan saponin (Praptiwi, 2005). Senyawa alkaloid adalah bahan organik yang mengandung nitrogen sebagai bahan dari sistem heterosiklik. Alkaloid bersifat basa yang mengandung satu atau lebih atom nitrogen, biasanya sebagai gabungan dari sistem siklik dan pada umumnya mengandung oksigen. Senyawa alkaloid banyak terkandung dalam akar, biji, kayu maupun daun dari tumbuhan. Peran alkaloid bagi tumbuhan sebagai zat racun yang melindungi tumbuhan dari gangguan serangga. Alkaloid bersifat basa, larut dalam air dan diketahui dapat menghambat sintesis protein dan merusak fungsi sel (Tobing, 1989). Dari sifatnya tersebut, dapat diketahui bahwa alkaloid lebih cepat larut, sehingga bahan aktif yang masuk kedalam tubuh serangga melalui kutikula, dan trakhea dapat langsung merusak fungsi sel serangga sehingga menyebabkan mortalitas.

Senyawa saponin bersifat sebagai racun dan antimikroba (jamur, bakteri, virus), bersifat antioksidan dan antikarsinogenik. Bahan yang bersifat sebagai anti bakteri dapat menganggu proses fisiologis dan menghambat terbentuknya komponen sel seperti sintesis dinding sel, membrane sitoplasma, sintesis protein dan sintesis asam nukleat (Soebandrio, 1995 dalam Ariati, 2008). Adanya kandungan saponin ditandai dengan pembentukan larutan koloid dalam air aglikonnya. Saponin ini memiliki berat molekul yang besar, larut dalam air, alkohol dan etanol. Saponin merupakan senyawa aktif permukaan dan bersifat seperti sabun, serta dapat dideteksi berdasarkan kemampuannya membentuk busa dan menghemolisis sel darah (Robinson, 1995).

Saponin yang memiliki aktivias racun kontak langsung bekerja ketika terjadi kontak antara serangga. Senyawa tersebut masuk melalui kutikula, atau trakhea atau langsung mengenai mulut serangga dan menembus integumen. Kneblock (1989) menyatakan bahan aktif yang memiliki sifat daya larut lebih tinggi dalam air akan mudah menembus lapisan fosfolipid membran sel sehingga lebih cepat menganggu fungsi fisiologis yang pada akhirnya sel akan mengalami kematian. Saponin memiliki sifat yang larut dalam air, sehingga bahan aktif lebih cepat larut. Kemampuannya membentuk busa sangat membantu penyerapan bahan aktif ketika terjadi kontak dengan serangga, sehingga bahan aktif lebih cepat masuk ke dalam tubuh serangga, menghemolisis sel darah, merusak fungsi sel dan dapat menyebabkan mortalitas pada serangga.

Penelitian sebelumnya menyebutkan bahwa tanaman mahoni yang mengandung senyawa saponin dan flavonoid berfungsi sebagai larvasida. Senyawa - senyawa tersebut juga mampu menghambat pertumbuhan larva, yaitu hormon otak, hormon edikson dan hormon pertumbuhan. Tidak berkembangnya hormon tersebut 
dapat menghambat pertumbuhan larva (Karimah, 2006).

Penelitian lain yang dilakukan oleh Aminah, dkk (2001) menyebutkan bahwa saponin dapat menurunkan tegangan permukaan selaput mukosa traktus digestivus larva menjadi korosif. Ukuran larva yang mati lebih panjang sekitar 1-2 mm karena terjadi relaksasi urat daging pada larva yang mendapat makan tambahan hormon steroid. Pupa tidak terpengaruh oleh saponin karena mempunyai struktur dinding tubuh yang terdiri dari kutikula yang keras sehingga senyawa saponin tidak dapat menembus dinding pupa. Callosobruschus sp merupakan serangga coleoptera yang memiliki struktur dinding tubuh yang keras dan tebal, namun bagian abdomen serangga ini memiliki struktur yang lebih lunak. Abdomen merupakan salah satu bagian terpenting dari tubuh serangga, dimana sistem-sistem metabolisme dalam tubuh serangga terjadi pada daerah abdomen. Jika bagian abdomen serangga terganggu maka sistem metabolisme serangga juga terganggu (Natawigena, 1990). Struktur abdomen yang lunak tersebut dapat memudahkan bahan aktif saponin masuk kedalam tubuh serangga dan menyebabkan korosif sehingga menyebabkan terganggunya sistemsistem metabolisme dan mengakibatkan mortalitas pada serangga Callosobruschus sp.

\subsection{Mortalitas Racun Syaraf}

Hasil analisis sidik ragam menunjukkan bahwa waktu perendaman ekstrak kulit batang "Kaju Ba'i" terhadap mortalitas serangga Callosobruschus sp pada racun syaraf memperlihatkan pengaruh yang nyata. Hal ini dapat dilihat pada pengamatan hari pertama sampai hari ke 4 (Tabel 2)

Tabel 2 Mortalitas Callosobruschus sp pada berbagai perlakuan untuk racun syaraf

\begin{tabular}{ccc}
\hline Perlakuan & $\mathrm{n}$ & Mortalitas $(\%)$ \\
\hline K0 & 10 & $0,3 \mathrm{~d}$ \\
K1 & 10 & $2,1 \mathrm{bc}$ \\
K2 & 10 & $2,2 \mathrm{bc}$ \\
K3 & 10 & $2,3 \mathrm{ab}$ \\
K4 & 10 & $2,7 \mathrm{a}$ \\
\hline
\end{tabular}

Keterangan: angka-angka yang diikuti huruf yang sama pada kolom yang sama, berarti tidak berbeda nyata pada uji Duncan's taraf 5\%. Data ditransformasi dengan $\square \mathrm{X}+0,5$

Hasil analisis statistik di atas menunjukkan bahwa perlakuan $\mathrm{K} 4$ dengan perendaman 4 hari menyebabkan mortalitas tertinggi sebanyak 2,7\%. Hal tersebut diakibatkan oleh jumlah bahan aktif perlakuan K4 lebih banyak sehingga jumlah partikel mikro insektisida yang terhirup lebih banyak dan menyebabkan terjadinya gangguan sistem syaraf. Gangguan yang terjadi mengakibatkan impul saraf tidak dapat berjalan secara normal sehingga serangga tidak mampu merespon rangsangan. Partikel mikro insektisida yang masuk melalui saluran pernapasan akan berikatan dengan enzim dalam darah yang berfungsi mengatur bekerjanya saraf, yaitu kholonesterase. Apabila kholonesterase terikat, maka enzim tersebut tidak dapat melaksanakan tugasnya sehingga syaraf terus-menerus mengirimkan perintah kepada otot-otot tertentu. Dalam keadaan demikian otot-otot tersebut senantiasa bergerak tanpa dapat dikendalikan, kejang-kejang dan 
mengakibatkan mortalitas (Anonim, 2010)

Perlakuan K3, K2 dan K1 meningkatkan mortalitas serangga berturut-turut lebih rendah. Hal ini disebabkan oleh perbedaan partikel mikro yang terhirup oleh serangga sehingga tingkat gangguan syaraf serangga berbeda. Jumlah pertikel mikro dipengaruhi oleh jumlah bahan aktif, semakin lama perendaman maka semakin banyak jumlah bahan aktifnya.

Mortalitas serangga paling rendah pada perlakuan $\mathrm{K} 0$ sebanyak $0,3 \%$ dan terjadi pada hari ketiga. Uji pra penelitian sebelumnya menunjukkan bahwa serangga Callosobruschus sp yang diberi perlakuan tanpa makan dan dimasukkan dalam toples mengalami mortalitas pada hari ketiga. Hal tersebut menandakan bahwa mortalitas yang terjadi tidak disebabkan oleh perlakuan tetapi akibat menurunnya daya kesintasan.

Ditinjau dari toksisitas, suatu senyawa dikatakan efektif bila mampu mematikan $80 \%$ hewan uji (Murfon dan Norton 1984 dalam Budiarto, 2000). Dari 5 perlakuan yang diuji tingkat mortalitas tidak mencapai $80 \%$, sehingga tidak efektif untuk diaplikasikan sebagai racun syaraf.

Hubungan antara lama perendaman dan peningkatan mortalitas serangga Callosobrushus sp diperlihatkan dengan persamaan regresi $\mathrm{Y}=1,0362+0,1630$ $\mathrm{X}$ berikut:

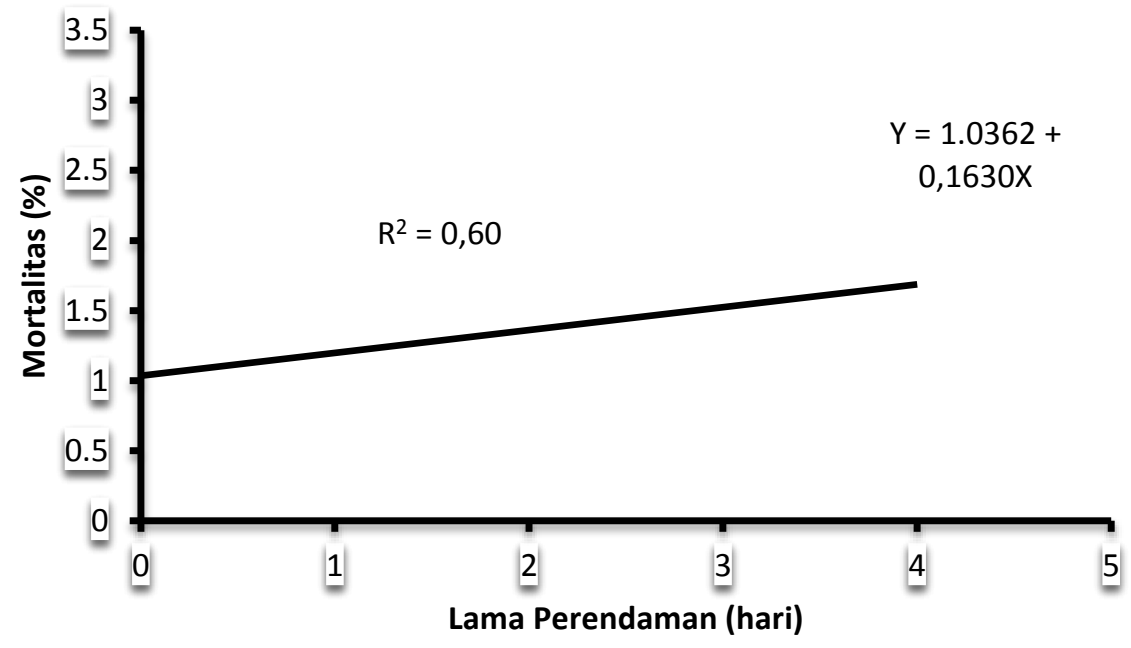

Gambar 2 Persamaan regresi antara lama perendaman Kaju Ba’i dan mortalitas serangga callosobrushus sp pada aktivitas racun syaraf

Dari grafik di atas dapat dilihat hubungan antara lama perendaman dan mortalitas serangga, dimana semakin lama perendaman maka semakin tinggi mortalitas serangga Callosobruschus sp. Lama perendaman meningkatkan mortalitas serangga sebanyak $0,1630 \%$ pada setiap taraf perendaman, sedangkan mortalitas serangga tanpa perlakuan perendaman sebanyak $1,06232 \%$. Peningkatan mortalitas serangga Callosobruschus sp pada racun syaraf $60 \%$ dipengaruhi oleh lama perendaman.

Peningkatan mortalitas yang tidak signifikan untuk masing-masing perlakuan dipengaruhi oleh sistem kerja syaraf serangga Callosobruschus sp. Ekstrak "Kaju Ba' $i$ " memiliki aroma yang sangat menyengat, namun tidak terlalu mempengaruhi sistem syaraf serangga Callosobruschus sp. Pada dasarnya senyawa alkaloid, triterpenod dan glokosida flovoroid memiliki fungsi 
yaitu mempengaruhi fungsi syaraf dengan menghambat enzim kolinesterase, sehingga akan terjadi gangguan transmisi rangsang yang menyebabkan menurunnya koordinasi otot, konvuli dan kematian bagi larva yang berkembang menjadi serangga dewasa (Endah dan Heri, 2000). Namun hal ini tidak berpengaruh pada serangga dewasa karena sistem susunan syaraf pusat serangga terdiri dari suatu rangkaian yang disebut ganglion yang dihubungkan oleh sepasang saraf netral. Ganglion merupakan suatu massa jaringan syaraf yang terdapat secara berpasangan pada setiap segmen yaitu pada daerah mata, antenna dan labrum (Natawigena, 1990).

Ekstrak "Kaju ba'i" memiliki aroma yang menyegat. Aroma tersebut terdeteksi oleh serangga Callosobruschus sp melalui organ penerima rangsang, namun tidak mempengaruhi kunjungan serangga tersebut terhadap kacang hijau yang diberi perlakuan. Hal ini mungkin dipengaruhi oleh aroma yang terdeksi oleh jaringan syaraf serangga dianggap berbahaya dan menggangu sistem transmisi syaraf, sehingga serangga Callosobruschus sp mengatur sistem kerja syaraf lebih intens untuk menutup jalan masuknya aroma bahan aktif agar tidak menganggu sistem kerja syaraf melalui ganglion. Keadaan tersebut menyebabkan sistem syaraf akan stabil dan serangga Callosobruschus sp tetap mengunjungi kacang hijau yang telah diberi perlakuan untuk melakukan aktivitas pengenalan habitat dan peletakkan telur.

Faktor lain yang mempengaruhi hal tersebut berhubungan dengan tipe sistem pernapasan dan sirkulasi serangga yang tidak mengalami gangguan jika salah satu sistemnya terganggu, sebab sistem syaraf serangga tidak sentralis seperti hewan vertebrata, melainkan menggunakan simpul-simpul saraf yang disebut ganglion. Tiap ganglion mengendalikan organ di dekatnya, apabila kepala serangga terputus, hanya fungsi-fungsi organ di kepala saja yang mati, sedangkan fungsi lain seperti pergerakan, pencernaan, dan pernapasan masih dapat berjalan (Jumar, 2000).

\section{Penurunan Aktivitas Peletakkan Telur}

Hasil analisis sidik ragam menunjukkan bahwa waktu perendaman ekstrak kulit batang "Kaju Ba' $i$ " terhadap penurunan aktivitas bertelur serangga Callosobruschus sp pada aktivitas anti oviposisi memperlihatkan pengaruh yang sangat nyata. Data tersebut disajikan pada tabel 3

Tabel 3 Penurunan aktivitas peletakkan telur Callosobruschus sp pada tiap perlakuan perendaman

\begin{tabular}{ccc}
\hline Perlakuan & N & Penurunan aktivitas bertelur $(\%)$ \\
\hline K0 & 10 & $0 \mathrm{a}$ \\
K1 & 10 & $45 \mathrm{~b}$ \\
K2 & 10 & $57 \mathrm{c}$ \\
K3 & 10 & $66 \mathrm{~d}$ \\
K4 & 10 & $75 \mathrm{e}$ \\
\hline
\end{tabular}

Keterangan: angka-angka yang diikuti huruf yang sama pada kolom yang sama, berarti tidak berbeda nyata pada uji Duncan's taraf 5\%. Data ditarsformasi dengan $\square \mathrm{X}+0,5$

Hasil analisis statistik dari tabel 3 di atas memperlihatkan bahwa perlakuan
K4 dengan perendaman 4 hari lebih efektif menurunkan aktivitas bertelur 
Callosobruschus sp sebanyak $75 \%$, K3 (66\%), K2 (57\%), K1 (45\%) sedangkan untuk K0 tidak menurunkan aktivitas bertelur Callosobruschus sp. Hal ini terjadi karena pengaruh senyawa aktif yang terkandung pada tanaman "Kaju $B a$ ' $i$ " dan perbedaan jumlah bahan aktif tanaman akibat lama perendaman. Perlakuan K4 dengan perendaman 4 hari memiliki jumlah bahan aktif yang lebih banyak sehingga pada saat kontak dan pemeriksaan serangga Callosobruschus sp mendeteksi adanya toksik yang menghambat aktivitas pemeriksaan inang sehingga aktivitas peletakkan telur tidak dapat dilakukan.

Serangga memiliki perilaku pengenalan habitat dan pemeriksaan inang untuk bertelur. Pengenalan habitat dipengaruhi oleh rangsangan kimia dan fisik. Rangsangan kimia berasal senyawa - senyawa padat atau cair yang berada sekitar inang, sedangkan untuk rangsangan fisik terjadi pada saat kontak serangga dan inang (Waseloh, 1981). Sedangkan proses pemeriksaan inang juga dilakukan setelah terjadi kontak, dimana sebelum bertelur serangga akan memeriksa inangnya, jika inang tidak cocok atau dianggap berbahaya, maka serangga akan mencari inang yang baru untuk meletakkan telurnya. Proses tersebut dibagi dalam empat fase yaitu (a) kontak dan pemeriksaan, (b) penusukan dengan ovipositor, (c) pemasukan ovipositor dan, (d) peletakkan telur. Keempat fase tersebut harus lengkap dan berurutan bila ada hambatan pada salah satu fase, proses penerimaan inang dimulai lagi dari awal. Penerimaan inang dipengaruhi oleh rangsangan fisik yang berupa ukuran, bentuk atau tekstur permukaan, warna, dan kandungan air (Arthur, 1981 dalam Wahyuni, 2006).

Serangga Callosobruschus sp tidak melakukan peletakkan telur karena pada saat pengenalan habitat dan pemeriksaan inang Callosobruschus sp telah mendeteksi adanya kandungan toksik pada kacang hijau perlakuan, sehingga proses penerimaan inang terhambat. Serangga Callosobruschus sp akan mencari inang alternatif lain untuk meletakkan telur yaitu pada dinding toples perlakuan. Proses pengenalan habitat dan pemeriksaan inang akan terus berlangsung, bila inang telah dianggap sesuai maka proses peletakkan telur akan dilakukan.

Perlakuan K3, K2 dan K1 menurunkan aktivitas peletakkan telur secara berturut-turut lebih rendah. Hal ini dipengaruhi oleh jumlah bahan aktif yang berkurang pada setiap perendaman sehingga menurunkan daya kerja toksik. Berkurangnya daya kerja toksik menyebabkan Callosobruschus sp meletakkan telur karena inang dianggap sesuai.

Perlakuan K0 tidak menurunkan aktivitas peletakkan telur. Hal ini disebabkan karena aquades yang diaplikasikan tidak mengandung bahan aktif yang bersifat toksik sehingga pengenalan habitat dan pemeriksaan inang berlangsung dengan baik dan proses peletakkan telur dapat dilakukan.

Hubungan antara lama perendaman dan penurunan aktivitas peletakkan telur serangga Callosobrushus sp diperlihatkan dengan persamaan regresi $\mathrm{Y}=2,9978$ - 0,2793X berikut: 


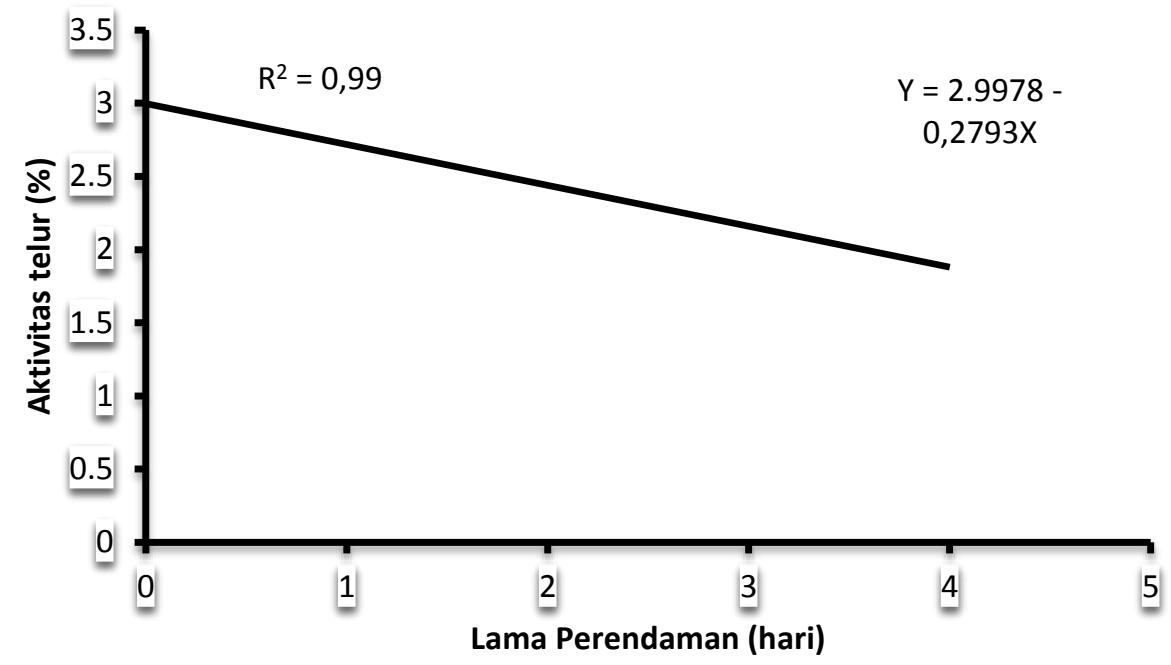

Gambar 3 Persamaan regresi antara lama perendaman Kaju Ba'i dan aktivitas bertelur serangga callosobrushus $\mathrm{sp}$

Dari grafik di atas dapat dilihat hubungan antara lama perendaman dan mortalitas serangga, dimana semakin lama perendaman maka semakin menurun aktivitas peletakkan telur serangga Callosobruschus sp. Lama perendaman menurunkan aktivitas peletakkan telur serangga sebanyak $0,2793 \%$ pada setiap taraf perendaman, sedangkan aktivitas bertelur serangga tanpa perlakuan perendaman sebanyak $2,9978 \%$. Penurunan aktivitas telur serangga Callosobruschus sp pada aktivitas anti oviposisi 99\% dipengaruhi oleh lama perendaman.

Penelitian sebelumnya menyatakan bahwa ekstrak dari biji Aglaia harmsiana memiliki kandungan bahan aktif alkaloid yang sama dengan "Kaju Ba'i" berpengaruh terhadap oviposisi dan reproduksi serangga Crocidolomia binotalis yang menyerang kubis (Kardinan, 2001).

Senyawa alkaloid dapat menekan sekresi hormon reproduksi yaitu estrogen dan androgen yang menunjukkan adanya kemampuan mendorong efek anti fertilitas (Winarno dkk, 1997). Ekawati (2008) menyebutkan bahwa pemberian ekstrak dan serbuk tanaman Syzygium aromaticum dan Vetiveria zizanioides yang mengandung senyawa alkaloid dan sterol yang dapat menghambat aktivitas anti oviposisi Sitophilus zeamais hingga $100 \%$.

Pengamatan aktivitas anti oviposisi dimana pada tiga jam pertama dan kedua Callosobruschus sp melakukan pengenalan habitat dan mencari inang untuk bertelur namun inang yang ditemukan tidak cocok, sehingga Callosobruschus sp mencari inang alternatif untuk meletakkan telur. Hal tersebut dipengaruhi oleh kandungan senyawa alkaloid dan saponin yang memiliki efek toksik, sehingga serangga Callosobruschus sp tidak meletakkan telurnya pada kacang hijau perlakuan. Telur diletakkan pada dinding toples perlakuan tidak pada kacang hijau. Serangga Callosobruschus sp akan selalu memeriksa inangnya kembali sebelum bertelur, dengan berkurangnya bahan aktif yang disebabkan oleh penguapan, maka inangnya telah dianggap aman, sehingga proses peletakkan telur akan dilakukan. 


\section{SIMPULAN}

Berdasarkan hasil penelitian dapat diambil kesimpulan bahwa:

1. Tingkat keefektifan dari pestisida nabati "Kaju Ba'i" (Aglaia tomentosa) pada setiap taraf perendaman berbeda, pada racun kontak perendaman 4 hari meningkatkan mortalitas hingga $99 \%, 3$ hari $(68 \%), 2$ hari $(42 \%)$, dan 1 hari $(25 \%$.)

2. Mortalitas serangga Callosobruschus sp pada aktivitas racun syaraf berbeda pada setiap taraf perendaman, 4 hari $(2,7 \%), 3$ hari $(2,3 \%), 2$ hari $(2,2 \%)$, dan 1 hari $(2,1 \%)$.

3. Perendaman 4 hari pada aktivitas anti oviposisi menurunkan aktivitas peletakkan telur Callosobruschus sp sebanyak 75\%, 3 hari (66\%), 2 hari (57\%) dan 1 hari (45\%).

4. Hubungan antara lama perendaman dengan tingkat keefektifan pestisida nabati "Kaju Ba'i" (Aglaia tomentosa) adalah semakin tinggi lama perendaman maka semakin tinggi tingkat keefektifan pestisida nabati "Kaju Ba'i" (Aglaia tomentosa), terutama pada racun kontak dan aktivitas anti oviposisi

\section{UCAPAN TERIMAKASIH}

Rasa terimakasih penulis sampaikan kepada pihak Program Studi Agroteknologi Fakultas Pertanian dan Balai Taman Nasional Kelimutu atas perijinan dan fasilitas yang diberikan kepada penulis.

\section{DAFTAR PUSTAKA}

Aminah N.S., Singgih H., Soetiyono P., Chaorul. 2001. S. rarak, D. metel dan E. prostate Sebagai
Larvasida Aedes aegypti. Cermin Dunia Kedokteran No. 131.

Anonim. 2010. Pestisida nabati. http://www.jakarta.go.id/distan/ BERITA/pestisi da\% 20nabati.htm

Ariati, Ni Komang. 2008. Aktivitas bakterisida ekstrak cem cem Spondias pinnata terhadap bakteri Erwinia chyrysanthemi penyebab busuk lunak Lidah buaya. Tesis. Universitas Udayana. Denpasar

Arnason, J.T., S. Mackinnon, A. Durst, B.J.R. Philogene, C. Hasbun, P. Sanchez, L. Poveda, L. San Roman, M.B. Isman, C. Satasook, G.H.N. Towers, P. Wiriyachitra, J.L. McLaughlin. 1993. Insecticides in Tropical Plants with Non-neurotoxic Modes of Action. p. 107-151. In K.R. Downum, J.T. Romeo, H.A.P. Stafford (eds.), Phytochemical Potential of Tropical Plants. New York: Plenum Press.

Budiarto. 2000. Pengaruh Ekstrak Kulit Buah Jeruk Siam Citrus Nobilis L. Terhadap Mortalitas Dan Perkembangan Hama Bubuk Beras Sitopilus oryzae L. Skripsi. Fakultas MIPA UNDIP. Semarang.

BPS Pertanian. 2008. Luas Panen, Produktivitas dan Produksi Kacang Hijau 2008. http://www.bps.go.id/tab_sub/vi ew.php?tabel=1\&daftar=1\&id subyek $=53 \&$ notab $=32$. Disidir pada tanggal 14 Mei 2010 
Direktorat Bina Perlindungan Tanaman Perkebunan [DBPTP] dan Direktorat Jenderal Perkebunan [Ditjenbun]. 1994. Upaya Pemanfaatan Pestisida Nabati dalam Rangka Penerapan Sistem Pengendalian Hama Terpadu. Prosiding Seminar Hasil Penelitian dalam Rangka Pemanfatan Pestisida Nabati: Balai Penelitian dan Pengembangan Pertanian dan Balai Penelitian Tanaman Rempah dan Obat. Bogor

Ekawati, Intan W. 2008. Pengaruh empat jenis ekstrak serbuk tanaman terhadap aktivitas peneluran Sitophilus zeamais (Coleoptera : curculionidae). Skripsi. IPB. Bogor

Endah, S dan Heri K. 2000. Manfaat ekstrak daun pare cegah demam berdarah. http://www.jawapos.co.id/index. php?act=detail_c\&id=255321. Disidir tanggal 6 November 2010.

Gomez, Kwanchai A. dan Arturo A. Gomez. 1987. Prosedur Statistik untuk Penelitian Pertanian. Universitas Indonesia Press. Jakarta

Hermawati, Darsih. 2004. Pengujian aktivitas biologi campuran ekstrak tumbuhan terhadap Callosobronchus sp. (Coleoptera : Bruchidae). Skripsi. IPB. Bogor

Indonesia, 2001. Serangga Hama Gudang.info@gizi.net. Disidir pada tanggal 13 Mei 2010
Jumar. 2000. Entomologi pertanian. Rineka Pustaka. Jakarta

Kardinan, A. 2001. Pestisida Nabati Ramuan dan Aplikasinya. Penebar Swadaya. Jakarta.

Kardinan, A. dan Ruhnayat, A., 2003. Mimba Budidaya dan Pemanfaatannya. Penebar Swadaya. Jakarta.

Karimah, L.N., 2006. Uji aktivitas larvasida ekstrak etanol $96 \%$ biji mahoni (swietenia mahagoni jacq) terhadap larva nyamuk Anopheles aconitus instar III serta profil kromotografi lapis tipisnya. F. Farmasi UMS. http://etd.library.ums.ac.id/gdl.p $\mathrm{hp}$ ? $\bmod =$ browse \&op $=$ read\&id $=\mathrm{j}$ tptums-gdl-sl-2007-ninyomansa6683. Disidir tanggal 7 November 2010.

Kneblock, K.A., A. Pauli., B. Iberl, H. Weigland., N. Weis. 1989. Anti bacterial and anti tungal properties of essential oil components. J. Essensial Oil Res.

Natawigena, Hidayat. 1990. Entomologi Pertanian. Orba Sakti. Bandung

Novizan, 2002. Membuat dan Memanfaatkan Pestisida Ramah Lingkungan. Agromedia Pustaka. Jakarta.

Pannell, 1992. A taxanomic monograph of the genus Aglaia Lour (Meliaceae). http:// www .bi ot ik.org/india/spesies/a/aglotome/a 
glotome_en.html. Disidir pada tanggal 31 Mei 2010

Praptiwi. 2005. Nilai peroksida tiga jenis aglaia (A. argentea, $A$. silvestria dan A. tomentosa. Pusat penelitian LIPI. Bogor

Prijono, D. 1988. Pengujian Insektisida. Penuntun praktikum jurusan Hama dan Penyakit Tumbuhan Fak. Pertanian IPB. Bogor.

Pusat Data dan Informasi Pertanian. 2004. Statistik Pertanian 2004. Pusat Data dan Informasi Pertanian, Jakarta.

Pustekom, 2005. Perlindungan Tanaman. http:// 209.85.175.104/ search?q cache : INeAFuGoOvsJ :fp.uns.ac.id/hamasains/id/ hamasains/dasar perlintan. Disidir pada 11 Mei 2010.

Robinson, Trevor. 1995. Kandungan Organik Tumbuhan Tinggi. Edisi keenam. Terjemahan Kokasih Padmawinata. Bandung : FMIPA ITB.

Sutoyo dan wirioadmodjo, B. 1997. Uji aktivitas daun nimba (Azadirachta indica), daun pahitan (Eupatorium inulifolium) dan daun kenikir (Tagetes spp) terhadap kematian larva Spodoptera litura (Lepidoptera: Noctuidae) pada tanaman tembakau. Dalam prosiding kongres perhimpunan entomologi Indonesia $\mathrm{V}$ dan symposium entomologi Universitas Padjajaran, Bandung 24-26 juni 1997
Tobing, Rangke. 1989. Kimia Bahan Alam. Departemen Pendidikan dan Kebudayaan. Direktorat Jendral Pendidikan Tinggi. Proyek Pengembangan Lembaga Pendidikan Tenaga kependidikan. Jakarta

Wahyuni, Sri. 2006. Studi Kompetisi Beberapa Jenis Parasitoid Terhadap Lalat Pengorok Daun Liriomyza Huidobrensis (Blanchard) (Diptera : Agromyzidae). Tesis. Universitas Udayana. Denpasar

Waseloh, R.M .1981. Host location by parasitoid in: Norddlund D.A, Jones R.L., Lewis, W.J. Editor. Semiochemical, Their role in pest control. New York: John wiley and sons. $\mathrm{P}$ 79-95

Winarno, M.W dan Sundari. 1997. Tanaman yang digunakan untuk kontrasepsi. Cermin dunia kedokteran. PT. Kalbe Farma. Jakarta 